\title{
Do lixão ao aterro: uma história socioambiental de Guarapuava/PR (1971-2011)
}

\author{
From dump to sanitary landfill: \\ A socio-environmental history of Guarapuava/PR(1971-2011)
}

Vladson Paterneze Cunha*

RESUMO

Partindo do pressuposto de que é possível historicizar o lixo e as relações sociais das quais resulta, demonstrando assim suas inter-relações com outros temas sociais, ambientais, políticos e econômicos nas sociedades capitalistas, procuramos compreender como foram formadas as políticas públicas ambientais relativas aos resíduos sólidos urbanos na cidade de Guarapuava, interior do estado do Paraná, entre os anos de 1971 e 2011. Utilizamos como fonte histórica os planos de gerenciamento de resíduos, leis, debates legislativos em atas, relatórios da administração municipal e jornais locais demonstrando de que forma o lixo se tornou um problema social, político e ambiental exigindo por parte dos representantes do Estado soluções adequadas. Empregando um referencial teórico-metodológico baseado no materialismo histórico, demonstramos que o problema do lixo se agrava na sociedade capitalista devido ao aumento da produção e do consumo que desconsidera os efeitos negativos de tais práticas para a natureza e para a sociedade. Assim, as soluções para os problemas relacionados ao lixo no meio urbano são vistas hegemonicamente por um aspecto técnico-econômico, segundo o qual todos os problemas são passíveis de serem resolvidos, bastando no caso do lixo, melhorar os sistemas de reciclagem ou implantar um aterro sanitário, opção esta adotada em Guarapuava.

Palavras-chave: História. Políticas Públicas. Lixo. Guarapuava.

ABSTRACT

Assuming that it is possible to historicize the trash and the social relations of which results, thus demonstrating their interrelations with other social, environmental, political and economic

"Mestre em História Social pelo Programa de Pós-Graduação em História Social - Universidade Estadual de Londrina (UEL). 


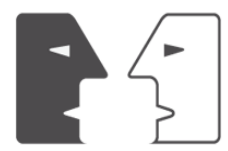

ANTÍTESES

issues in capitalist societies, we seek to understand how public environmental policies were formed waste municipal solid in Guarapuava, the state of Paraná, between the years 1971 and 2011. Used as a historical source plans for waste management, laws, legislative debates in minutes, reports of municipal administration and local newspapers demonstrating how garbage has become a social, political and environmental problem requiring by representatives of the State appropriate solutions. Employing a theoretical and methodological framework based on historical materialism, we demonstrated that the garbage problem worsens in capitalist society due to increased production and consumption that disregards the negative effects of such practices for nature and society. Thus, the solutions to the problems related to garbage in urban areas are seen by a hegemonic techno-economic, whereby all problems are likely to be resolved aspect, just in case the waste, improve recycling systems or deploy a landfill health, this option adopted in Guarapuava.

Keyword: History. Public Policy. Garbage. Guarapuava. 